\title{
Pendidikan Politik dalam Menangkal Pemahaman Radikalisme Agama bagi Pemuda Muhammadiyah di Kecamatan Pariaman Utara, Kota Pariaman
}

\author{
Zulfadli1 $^{1}$, Sadri Chaniago ${ }^{1}$, dan Heru Permana Putra ${ }^{2}$ \\ 1Fakultas Ilmu Sosial dan Ilmu Politik, Universitas Andalas, Kampus Limau Manis, Padang, 25163. Indonesia \\ ${ }^{2}$ Fakultas Ushuluddin Adab dan Dakwah, Institut Agama Islam Negeri (IAIN), Bukittinggi, 26181. Indonesia \\ E-mail: zulfadli@soc.unand.ac.id
}

Keywords:

deradicalisation moderatism, Muhammadiyah, religious radicalism, young people

Kata Kunci: deradikalisasi, kaum muda, moderatisme agama, Muhammadiyah, radikalisme agama

\begin{abstract}
This community service is caused by the tendency to strengthen the understanding of religious radicalism in society. Understanding radicalism obtained by the public along with developments in technology and information such as social media. In general, the understanding of radicalism has penetrated specific target groups such as young people. On the one hand, young people are among those who are vulnerable and potentially exposed to religious radicalism. On the other hand, young people are also potential groups in counter the understanding of religious radicalism. Community organizations such as Muhammadiyah have a strategic role in counteracting understanding of religious radicalism. Young people have a tactical and strategic role in counteracting the understanding of religious radicalism that tends to strengthen lately. Therefore, the seeding of thoughts, ideas, ideas of counter-radicalism and religious de-radicalism becomes relevant to carry out. The method used was a brainstorming technique, to find out the solution of a problem by gathering ideas spontaneously from group members. After that, it was then followed by a lecture method that ends up with a discussion. The results of this devotion showed an understanding of religious moderate for Muhammadiyah youth as a counter to understand the religious radicalism.
\end{abstract}

\begin{abstract}
ABSTRAK
Pengabdian masyarakat ini dilatarbelakangi oleh kecenderungan menguatnya pemahaman radikalisme agama di masyarakat. Pemahaman ini semakin mudah diperoleh masyarakat seiring dengan perkembangan teknologi dan informasi seperti media sosial. Secara umum, pemahaman radikalisme sudah merambah kepada kelompok-kelompok yang spesifik termasuk kaum muda. Di satu sisi, kaum muda termasuk kelompok yang rentan dan potensial terpapar paham radikalisme agama. Di sisi lain, kelompok muda juga kelompok yang berpotensi untuk menangkal pemahaman tersebut. Organisasi masyarakat seperti Muhammadiyah memiliki peran yang strategis perihal ini. Pemudanya memiliki peran taktis dan strategis dalam menangkal pemahaman radikalisme agama yang cenderung menguat tersebut. Oleh karena itu penyemaian pemikiran, gagasan, ide kontraradikalisme dan deradikalisme agama menjadi relevan untuk dilaksanakan. Kegiatan dilaksanakan dengan metode curah pendapat, mengumpulkan gagasan secara spontan guna mengetahui penyelesaian suatu masalah dari anggota kelompok. Selanjutnya, metode ceramah yang diakhiri dengan diskusi. Hasil pengabdian ini menunjukkan pemahaman moderatisme agama oleh kaum muda Muhammadiyah bisa sebagai konter terhadap pemahaman radikalisme agama.
\end{abstract}




\section{PENDAHULUAN}

Era reformasi menandai babak baru perubahan lanskap sistem politik di Indonesia. Di satu pihak ditandai dengan peralihan rezim dari sistem politik yang otoritarian menuju sistem politik demokratis. Perubahan politik yang terjadi misalnya ditandai dengan amandemen terhadap Undang-Undang Dasar 1945, pengesahan sejumlah peraturan perundang-undangan dalam memberikan perlindungan, penghormatan dan pengakuan terhadap hak dan kebebasan sipil masyarakat, pembentukan sejumlah institusi-institusi negara yang demokratis, dan terbentuknya multi organisasi masyarakat, pers, dan partai politik yang sangat variatif dan lain sebagainya (Suseno, 2014).

Di sisi lain era reformasi juga memiliki dimensi fungsi latennya yaitu dimana euforia politik reformasi ditandai dengan kemunculan sejumlah gerakan kelompok-kelompok radikal yang memiliki karekteristik, ideologi dan gerakan dengan ciri masing-masing. Seperti kelompok Jihadis, Teroris, dan kelompok ekstemis. Aktivitas dan gerakan mereka berbeda dengan organisasi masyarakat arus utama seperti Naddatul Ulama (NU) dan Muhammadiyah. Sehingga kemunculan gerakan radikal pasca reformasi disinyalir sebagai bagian dari kebangkitan gerakan Islam non mainstream dan kebangkitan Islam politik di Indonesia pasca reformasi (B. S. dan Z. Qodir, 2015).

Terbukanya kran demokrasi menjadi lahan subur tumbuh dan berkembangnya ideologi radikal. Menurut Nadirsyah Hosen (2019), mereka yang disebut sebagai kelompok radikal adalah (1) Kaum takfiri yang menganggap kelompok diluar kelompoknya adalah kafir. (2) Kelompok jihadis yaitu orang melakukan pembunuhan terhadap orang lain atas nama jihad tanpa dibenarkan oleh agama. (3) Gerakan yang ingin menganti sistem yang ada dengan ideologi khilafah ataupun Negara Islam.

Ideologi radikal yang berkembang cenderung mengedepankan ajaran Al wal wa'l bara sebagai landasan utama dalam menyebarkan gagasannya. Pada dasarnya al-wala berarti mencintai, mendukung, menolong, mengikuti dan mempertahankan. Al bara berarti meremehkan dan mencela. Doktrin ini menyiratkan bahwa tiap muslim yang menyatakan diri beriman harus mencintai dan menolong dan mempertahankan Islam dan umat Islam lainnya sekaligus pada saat yang sama menjauhkan dirinya dari pengingkaran dan pengaruh orang kafir. Secara umum ajaran ini menjelaskan perbedaan mutlak antara dunia orang beriman dan dunia orang tidak beriman (kafir.) Al wala wa'l bara sebagai prinsip yang harus diikuti secara konsisten oleh seluruh muslim agar dapat menjawab tantangan dari musuh-musuh Islam (Hasan, 2012).

Diskursus tentang radikalisme bukanlah suatu konsep yang sederhana dalam menjelaskan fenomena pemahaman radikal dan aksi-aksi terorisme yang terjadi di masyarakat. Dalam tingkat tertentu sering disalahpahami antara radikalisme dan terorisme dimaknai secara sama. Padahal radikalisme dan terorisme tidak selalu dimaknai secara sama. Ada gerakan, aliran, pemikiran tertentu yang radikal akan tetapi kelompok tersebut tidak melakukan aksi terorisme ataupun ekstremisme. Banyak organisasi radikal tapi ia tidak melakukan aktivitasnya dengan cara-cara kekerasan. Sebagai contoh kelompok Hizbut Tahrir Indonesia (HTI) adalah kelompok yang memiliki ideologi, pandangan radikal yang ingin mengganti suatu sistem pemerintahan dengan sistem yang ia cita-citakan yaitu khilafah islamiyah. Akan tetapi dalam melaksanakan citacitanya ia tidak melakukan cara-cara kekerasan, teror ataupun ekstremis (Zulfadli, 2018). Selain itu radikalisme sebagai sebuah paham melibatkan proses radikalisasi yang cukup komplek.

Menurut Fealy dan Hooker (2006), Islam radikal mengacu pada gerakan-gerakan Islam yang ingin melakukan perubahan secara dramatis dalam masyarakat dan negara. Menegakkan hukum Islam secara komprehensif dan penegakan nilai-nilai Islam. Muslim radikal cenderung memiliki interpretasi literal Al-Qur'an, terutama bagian-bagian yang berkaitan dengan hubungan sosial, perilaku keagamaan dan hukuman kejahatan (Hooker, 2006).

Radikalisme tidak muncul begitu saja. Melainkan ia mengalami penguatan dalam proses yang cukup komplek dalam diri seseorang yang disebabkan oleh faktor internal dan eksternal yang dialami seorang individu. Faktor-faktor tesebut, adalah politik, sosial, ekonomi, ideologi, 
kemiskinan, pengangguran, faktor internasional dan lain sebagainya. Radikalisme membutuhkan proses radikalisasi dalam diri seseorang. Ia melalui tahapan sejumlah tahapan yaitu pengenalan, pananaman, penghayatan, dan penguatan proses keyakinan. Tahapan-tahapan inilah yang disebut dengan proses radikalisasi.

Apabila proses radikalisasinya berjalan dengan baik sesuai dengan tahapan proses radikalisasi, maka akan melahirkan radikalisme. Seorang yang sudah tersentuh paham radikalisme akan cenderung memiliki loyalitas dalam bentuk keberpihakan, pembelalaan dan pembuktiaan terhadap apa yang diyakininya. Sehingga tidak heran prilaku radikal yang dialami seseorang menyimpang, berbahaya, merusak, anti sosial karena ideologi radikal yang diyakininya. Radikalisasi memerlukan proses yang dilakukan oleh seseorang atau kelompok untuk mendoktrin orang lain agar mempunyai paham dan aksi radikal destruktif dengan melakukan aksi terror. Proses ini dilakukan dengan berbagai cara dan pendekatan, salah satunya dengan indoktrinasi paham atau ajaran agama (Karwadi, 2014).

Fenomena radikalisme ini seringkali disandarkan dengan paham keagamaan, meskipun terdapat faktor lain penyebab lain atau motif orang melakukan aksi kekekerasan dalam bentuk terorisme. Seperti motif politik ideologi terorisme, motif agama dan motif ideologis (Zulfadli, 2017). Rentetan kejadian terorisme yang pernah terjadi di Indonesia secara buruntun merupakan indikasi bahwa radikalisme tumbuh dan berkembang di masyarakat. Karena memang ada orang yang betul-betul mendedikasikan hidupnya untuk menjadi teroris, mengembleng teroris, mengajarkan ilmu teror dan meyakinkan orang untuk mengikuti ideologi teroris. Meskipun radikalisme dan terorisme adalah dua hal yang berbeda akan tetapi radikalisme merupakan tangga menuju terorisme. Karena pada umumnya pelaku teror itu adalah orang yang pada awalnya mempunyai pemahaman radikal.

Radikalisme bukan hanya tumbuh di lingkungan orang-orang miskin dan marjinal, tetapi juga di lingkungan kaum terdidik dan berada, termasuk mereka yang berasal dari perguruan tinggi terkemuka. Mereka mengedepankan identitas keislaman hingga terpapar paham radikalisme dan terorisme (Abubakar et al., n.d.). Kaum muda termasuk kelompok yang rentan terpapar paham radikalisme. Salah satu penyebabnya adalah media sosial memiliki peran yang besar dalam memproduksi dan mereproduksi wacana radikalisme dan ekstremisme. Media sosial meningkatkan peluang orang atau sekelompok orang menjadi radikal, sebagai pengaruh penjangkauan dan pelibatan, melalui penyebaran informasi, komunikasi dan propaganda keyakinan-keyakinan ekstrim (Sosial, 2017). Di sisi lain pemuda memiliki peran yang sangat penting dalam menghentikan laju radikalisme Islam. Radikalisme membutuhkan upaya deradikalisasi secara efektif dan masif. mendefinisikan deradikalisasi sebagai suatu bentuk upaya menetralisasi paham-paham radikal melalui pendekatan interdisipliner, seperti politik, hukum, psikologi, agama, sosial-budaya bagi mereka yang dipengaruhi atau terpapar paham radikal dan/atau pro-kekerasan. Salah satu cara dalam menagkal laju radikalisme agama adalah dengan pendekatan deradikalisasi.

Ideologi radikalisme sudah mulai disebarkan kedalam dunia pendidikan dan kalangan anak muda. Paham radikalisme melakukan infiltrasi ideologi melalui jaringan pendidikan seperti sekolah maupun perguruan tinggi. Mahasiswa ditengah proses pencarian identitas diri menjadi objek sasaran dalam menyebarkan paham radikalisme keagamaan. Hal ini juga didukung oleh minimnya pengetahuan agama yang diperoleh sebelumnya, seiring dengan mulai terbuka dan membaca terhadap pengetahuan baru, maka tiba-tiba menganggap apa yang dibacanya tersebut sebagai sesuatu yang mutlak. Kondisi ini juga didukung oleh organisasi yang memang berorientasi mengembangkan pemahaman radikal sehingga mudah dalam melakukan proliferasi paham-paham radikal.

Faktor penyebab munculnya radikalisme kaum muda muslim di Indonesia adalah (1) Transisi politik pada era reformasi penuh dengan kesempatan politik yang penuh dengan gejolak ketidakpastian. (2) Transformasi ideologi radikal Islam yang memang memiliki akar sejarahnya pada masa lalu. (3). Tingginya angka pengangguran kalangan pemuda di Indonesia. Aksi radikalisme yang alami oleh kalangan pemuda merupakan aksi identitas kolektif yang 
disebabkan oleh krisis identitas ditengah ketidakpastian perubahan sosial politik yang mereka alami (Azca, 2013).

Pemuda memiliki potensi dalam tiga posisi sekaligus terkait deradikalisasi. Yaitu sebagai korban radikalisme, pelaku, dan penopang gerakan deradikalisasi terhadap kehidupan masyarakat. Jika sebelumnya pemuda masih sebatas pendukung radikalisme, namun belakang sudah diarahkan menjadi pelaku utamanya. Pemuda sangat rentan terhadap radikalisme. Studi terdahulu yang dilakukan oleh sejumlah lembaga menujukkan penguatan kaum muda terpapar paham radikalisme. (Setara Foundation, 2015; Wahid Institute, 2016; Maarif Institute, 2015), dan di media sosial (Alvara Research Center, 2017).

Kalangan muda termasuk golongan rentan dari paham radikalisme dan terorisme di Indonesia. Di tengah ketidakpastian, kegamangan dan kegagapan dalam menghadapi masa depan. Peluang-peluang politik seperti ini yang dimanfaatkan oleh penyebar ideologi radikal dalam melakukan mobilisasi untuk menarik simpati dan merekrut kelompok anak-anak muda. Sehingga perubahan sosial dan politik merupakan daya tarik dalam memobilisasi kalangan pemuda (Ahnaf, 1970). Kondisi ini juga didukung oleh pengaruh teknologi dan informasi sehingga generasi ini terbiasa menyederhanakan persoalan-persoalan sosialnya. Dalam menghadapi persoalan seperti itu, frustasi dapat dengan mudah menghinggapi kalangan anak muda. Masifnya pengaruh radikalisme laksana penyejuk hawa dengan menawarkan mimpi dan harapan-harapan tentang perubahan dan masa depan yang lebih baik. Kalangan muda termasuk generasi milenial sangat akrab dengan teknologi informasi, media sosial seperti facebook, instagram, twitter, telegram dan lain sebagainya. Narasi-narasi yang mengajak orang untuk masuk surga dengan cara mudah adalah dengan mengorbankan diri menjadi terorisme, sangat banyak ditemukan di media sosial.

Mayoritas dari teroris yang beraksi di Indonesia masih berusia muda, termasuk 12 pelaku bom bunuh diri di berbagai tempat di Indonesia sejak tahun 2000, semuanya berusia antara 1831 tahun. Melihat kondisi inilah, elemen pemuda harus ikut terlibat dalam proses deradikalisasi. Tidak cukup menggantungkan hal itu pada pemerintah, perlu ada kekuatan lain, yaitu elemen pemuda, yang menjelaskan ke masyarakat, bahwa yang dilakukan teroris dan paham yang mereka percayai itu salah. Para pelaku radikalis dengan mudah menyebarkan keyakinan mereka kepada anak-anak muda karena tidak ada kekuatan lain di masyarakat yang mengimbangi kekuatan teroris tersebut dalam menjelaskan apa yang sebetulnya terjadi. Inilah tantangan pemuda saat ini, tidak hanya di Indonesia tetapi di seluruh dunia.

Deradikalisasi terhadap kaum muda yang terpapar paham radikalisme dan pendidikan politik terhadap kalangan muda dalam menangkal paham radikal relevan untuk dikembangkan. Deradikalisasi merupakan upaya dalam memutus mata rantai terorisme. Deradikalisasi terhadap orang yang terhinggapi paham radikal lebih sulit dilakukan dibandingkan dengan seseorang yang menerima paham radikal. Karena pemikiran mereka cenderung tertutup, ekslusif, dari orang-orang yang tidak sepaham dengan mereka. Karena sangat terkait ideologi dan keyakinan yang dijadikan sebagai dasar seseorang dalam melihat dunia (Z. Qodir, 2013).

Selama ini pemerintah melalui Badan Nasional Penaggulangan Terorisme (BNPT) melakukan upaya pencegahan terhadap terorisme melalui dua pendekatan. Yaitu kontraradikalisme, pendekatan yang mengedepankan pencegahaan dalam penguatan nilai-nilai kebangsaan, nasionalisme, toleransi, haromoni, pancasila dan narasi-narasi positive dalam menangkal pemaham radikal. Pendekatan kedua yaitu deradikalisasi, pendekatan yang dilakukan terhadap orang yang sudah tersusupi paham radikal dengan beragam upaya pendekatan terhadap para korban terorisme.

Provinsi Sumatera Barat termasuk salah satu provinsi yang rentan terhadap potensi berkembangnya paham radikalisme. Penangkapan pelaku terorisme beberapan tahun terakhir menunjukkan bahwa pelaku terorisme banyak berkembang di Sumbar. Hal ini semakin diperkuat oleh penyataan Al Chairdar, bahwa terdapat terdapat kurang lebih 3000 orang bibit terorisme yang tergabung dalam Jamaah Ansharut Tauhid, Jamaah Ansharut khilafah, Jamaah Ansharut daulah di Sumatera Barat ("Sumatra Barat Jadi Sasaran Teroris?," 2018). 
Pengabdian terhadap kaum muda dikalangan pemuda Muhammadiyah urgen dilakukan dengan beberapa pertimbangan. Pertama Muhammadiyah merupakan ormas terbesar di Sumatera Barat, yang didukung oleh institusi pendidikan yang sangat luas dan banyak. Oleh karena itu, diseminasi pendidikan politik deradikalisasi perlu digalakkan terhadap pemuda Muhammadiyah. Diseminasi permikiran-pemikiran deradikalisasi mendesak dilakukan. Kedua sebagai ormas yang memiliki semangat berkemajuan (progresif), pemuda Muhammadiyah memiliki peran strategis dalam menyemaikan ide dan gagasan dalam menangkal paham-paham radikal yang berkembang di masyarakat maupun di media sosial. Meskipun kaum muda rentan terhadap potensi radikalisme, disisi lain, kaum muda memiliki peran penting dalam menyemaikan pemahaman deradikalisai kepada masyarakat umum.

\section{Permasalahan Mitra}

Berdasarkan kondisi yang ada, ditemukan beberapa permasalahan yang tengah dihadapi pemuda terkait pendidikan politik deradikalisasi dalam menangkal pemahaman radikalisme bagi pemuda Muhammadiyah.

1. Pemuda merupakan salah satu kelompok yang cukup rentan dan potensial terpapar pemahaman radikalisme dan sering dijadikan target oleh paham-paham radikalisme.

2. Paham radikalisme dengan mudah berkembang belakangan ini, seiring dengan kemajuan teknologi informasi. Pemuda sering menggunakan media sosial dalam memproduksi dan mereproduksi paham-paham radikalisme.

3. Muhammadiyah sebagai organisasi terbesar, memiliki peran strategis dan taktis dalam menangkal pemahaman radikalisme terutama kalangan pemuda Muhammadiyah yang cukup aktif dan progresif dalam menyebarkan gagasan, ide, pemikiran deradikalisasi.

4. Pendidikan politik dalam menangkal pemahaman radikalisme akan semakin efektif bila dikembangkan melalui lembaga-lembaga pendidikan Muhammadiyah.

\section{Tujuan Kegiatan}

Tujuan pelaksanaan kegiatan pendidikan politik deradikalisasi dalam menangkal pemahaman radikalisme bagi pemuda Muhammadiyah di Kecamatan Pariaman Utara, Kota Pariaman adalah sebagai berikut:

1. Meningkatkan pemahaman deradikalisasi dalam menangkal pemahaman radikalisme bagi pemuda Muhammadiyah.

2. Menyebarkan paham deradikalisasi kepada pemuda Muhammadiyah dan mendeseminasikan gagasan dan ide-ide deradikalisasi kepada masyarakat luas.

3. Mewaspadai kerentanan dan potensi kaum muda dari paham-paham radikalisme.

4. Mendorong kaum Muhammadiyah secara aktif dalam menolak paham radikalisme.

\section{Solusi yang ditawarkan}

Berdasarkan analisis situasi dan permasalahan mitra di atas maka solusi yang ditawarkan dalam pendidikan politik deradikalisasi dalam menangkal pemahaman radikalisme di Kota Pariaman adalah:

1. Melakukan transfer pengetahuan dan pemahaman pendidikan politik deradikalisasi dalam menangkal pemahaman radikalisme.

2. Memberikan keterampilan dalam mengembangkan pendidikan politik deradikalisasi dalam menangkal pemahaman radikalisme.

\section{METODE}

Progam pelatihan pendidikan politik deradikalisasi dalam menangkal pemahaman radikalisme menerapkan metode brainstorming yang dilaksanakan secara komunikatif, interaktif, dan partisipatif. Metode ini memaksimalkan peran narasumber, fasilitator/instruktur 
dan peserta melalui studi kasus, simulasi dan contoh-contoh yang kongkrit. Peserta pelatihan adalah Pemuda Muhammadiyah di Kota Pariaman sebanyak 50 orang.

Adapun metode tersebut dilakukan dengan langkah-langkah mengikuti Siklus Pembelajaran Berdasarkan Student.

\section{a. Diskusi kelompok}

Mitra dibagi menjadi kelompok kecil (6 orang) untuk membahas suatu topik tertentu secara mendalam. Seluruh anggota terlibat aktif dan dapat kesempatan untuk mengemukakan pendapatnya. Dalam kelompok terdiri pemuda Muhammadiyah yang terdapat di Kota Pariaman.

\section{b. Diskusi pleno}

Diskusi pleno di antara semua peserta akan digunakan untuk memberikan pengetahuan dan pemahaman yang gamblang konsep pendidikan politik deradikalisasi dalam menangkal pemahaman radikalisme. Selain itu, diskusi pleno bisa dipakai sebagai forum untuk mendiskusikan hasil diskusi kelompok.

\section{c. Curah pendapat}

Curah pendapat dilakukan untuk mendapat sebanyak mungkin masukan dari seluruh peserta dalam waktu pendek sebagai dasar untuk diskusi selanjutnya. Dalam sesi ini kualitas masukan dari peserta belum dijadikan hal yang penting. Pada saat curah pendapat dilakukan peserta lain belum diberikan kesempatan untuk memberikan tanggapan terhadap masukan masingmasing.

\section{d. Ceramah}

Untuk menjelaskan suatu konsep, definisi, proses yang terkait dengan pendidikan politik deradikalisasi dalam menangkal pemahaman radikalisme menggunakan teknik ceramah. Materi ceramah ditayangkan menggunakan alat power point dan pantulan LCD Projector. Namun pengusul membatasi waktu ceramah supaya tidak membosankan peserta dan mendorong peserta untuk berpikir kritis dan berperan aktif.

\section{Materi}

Materi/Silabus pelatihan pendidikan politik deradikalisasi dalam menangkal pemahaman radikalisme ini meliputi topik-topik sebagai berikut:

1. Pendidikan Politik

2. Wawasan kebangsaan

3. Kontra deradikalisasi pemahaman radikalisme

4. Metode dan teknik mengembangkan diseminasi pendidikan politik deradikalisasi dalam menangkal pemahaman radikalisme

5. Simulasi atau pelatihan

\section{HASIL DAN PEMBAHASAN}

Kegiatan dilakukan di Aula Camat Pariaman Utara, Kota Pariaman pada tanggal 04 November 2018, dengan tema "Pendidikan Politik Deradikalisasi Bagi Angkatan Muda Muhammadiyah Cabang Pariaman Utara”, dengan urutan materi sebagai berikut:

\section{Pemateri 1: Zulfadli, SHI.M.Si}

\section{Pokok Pembahasan}

Ormas Islam arus utama (mainstream) seperti Nahdatul Ulama (NU) dan Muhammadiyah memiliki peran yang sangat penting dalam menjaga persatuan dan kesatuan bangsa. Dalam perjalanan sejarah, kiprah dua organisasi ormas Islam terbesar di tanah air ini tampil sebagai garda terdepan dalam melepaskan Indonesia dari pemerintahan kolonial Belanda di satu sisi, dan kontribusi penting dalam proses kemerdekaan Indonesia di sisi lain.

Oleh karena itu, komitmen bersama anara NU dan Muhammadiyah beberapa waktu yang lalu dalam meneguhkan komitmen kebangsaan yang patut diapresiasi secara bersama. (Padang 
Ekspress, 1/11/2018). Pertemuan tersebut menghasilkan beberapa komitmen penting yaitu: Pertama, berkomitmen kuat menegakkan keutuhan dan kedaulatan NKRI. Kedua, mendukung sistem demokrasi dan proses demokratisasi sebagai mekanisme politik kenegaraan. Ketiga, meningkatkan komunikasi dan kerja sama yang konstruktif. Keempat, semua pihak berkomitmen mengedepankan kearifan, kedamaian, toleransi dan kebersamaan di tahun politik ini.

Salah satu problem dan tantangan ormas moderat hari ini adalah ormas moderat tidak lagi semata-mata dijadikan rujukan dalam model keberagaman Islam di Indonesia. Ormas moderat berada dalam persimpangan jalan seiring lahir dan munculnya ormas-ormas Islam baru (non mainstream) dan alternatif lainnya mulai dari sifatnya fundamentalis, radikalis, konservatif dan puritan dan lain sebagainya. Ormas non mainstream dan kebangkitan Islam politik kembali menguat dalam beberapa waktu belakangan.

Kondisi ini semakin diperkuat berdasarkan temuan hasil penelitian dari Pusat Studi Budaya dan Perubahan Sosial, yang berjudul Radikalisme di Website dan Media Sosial (SeptemberNovember, 2017). Hasil penelitian tersebut menunjukkan radikalisme yang terjadi di kalangan anak muda lebih banyak disebabkan karena mereka mengakses konten-konten radikal yang terdapat dalam situ-situs organisasi Islam non-afiliasi. Karena sebagain besar website Islam yang non-afiliasi mendukung radikalisme. Seperti Pesan-pesan radikal dan ujaran kebencian ditemukan di sebagian website non-afiliasi. Selain itu, yang lebih menarik dari penelitian ini, bahwa generasi muda era millennial lebih banyak mengunjungi situs website ormas Islam nonafiliasi dibadingkan dengan situs-situs ormas Islam arus utama, seperti Nahdatul Ulama (NU Online), Muhammadiyah (Suara Muhammadiyah).

Jika pada tahun 1980-an sebagai negara demokrasi dengan mayoritas berpenduduk muslim di Indonesia melalui maha karya Civil Islam: Muslims and Democratization in Indonesia (2000) karya Robert W. Hefner bahwa Indonesia merupakan salah satu negara demokratis yang didukung oleh kelompok masyarakat sipil Islam yang kuat. Buku ini menjadi karya klasik dan monumental karena secara jernih melihat tumbuh kembangnya tradisi Islam demokratik di Indonesia. Civil Islam mengatakan bahwa proses demokratisasi dan ide-ide tentang demokrasi, civil society, civic pluralism, civil liberties, dan lain sebagainya yang selama ini menjadi "maskot Barat" juga bisa ditemukan di negara-negara mayoritas berpenduduk Muslim. Tumbuh dan berkembangnya tradisi demokrasi dalam mayoritas masyarakat muslim di Indonesia, karena didukung oleh ormas mainstream arus utama yang disebut dengan Civil Islam, yaitu NU dan Muhammadiyah.

Hasil temuan Hefner pada masa Orde Baru sesungguhnya juga sejalan dengan temuanya Syaiful Mujani, dalam buku Muslim Demokrat, Islam, Budaya Demokrasi, dan Partisipasi Politik di Indonesia Pasca Orde Baru (2007). Proses demokratisasi yang terjadi di Indonesia terdapat kesesuaian (compatibilitas) antara nilai-nilai Islam dengan nilai-nilai demokrasi yang dimotori oleh muslim demokrat Indonesia yang diwakili oleh NU dan Muhammadiyah. Ormas mainstream memiliki peran yang strategis dalam memoderatkan kaum muslim di Indonesia. Ormas moderat semakin mendapatkan tantangannya di tengah semakin menguat derasnya arus intoleransi, radikalisme, dan tindakan terorisme yang semakin meningkat beberapa waktu belakangan ini.

Paham radikalisme merupakan anak tangga menuju prilaku terorisme. Keterlibatan berbagai pihak dalam menangani masalah radikalisme dan terorisme sangat diharapkan. Tujuannya adalah untuk mempersempit ruang gerak radikalisme dan terorisme. Dalam konteks di atas, pemuda memiliki peran yang sangat penting dalam menghentikan laju radikalisme Islam. Karena beberapa anak muda memilih situs berbau radikalisme (Pariaman Today, 4/11/2018).

Meningkatnya aktifitas anak muda Islam dalam mengakses konten-konten yang mengarah pada tindakan radikalisme, maka untuk itu penting untuk diberikan pendidikan dalam pencegahan tindakan tersebut. Anak muda merupakan aset bangsa, jadi apabila banyak yang terlibat aktifitas radikalisme maka ini akan menjadi ancaman masa depan bangsa. Pengabdian pendidikan deradikalisasi terhadap kaum muda dikalangan pemuda yang berasal dari ormas moderat sangat penting dengan beberapa pertimbangan. Pertama, Diseminasi pendidikan politik deradikalisasi perlu digalakkan terhadap kaum pemuda. Kedua, ormas moderat dengan dukungan sarana dan prasarana dan jaringan yang dimilikinya memiliki peran strategis dalam 
menyemaikan ide dan gagasan deradikalisasi. Meskipun kaum muda rentan terhadap potensi radikalisme, disisi lain, kaum muda memiliki peran penting dalam menyemaikan pemahaman deradikalisai kepada masyarakat secara umum. Radikalisme sangat banyak terjadi diberbagai sektor, ia hadir berupa pemahaman-pemahaman, salah satunya disusupi melalui sektor pendidikan. Dengan menagajarkan jargon-jargon yang mengupayakan tertanamnya paham radiklisme tersebut. Paham ini memaknai bahwa kebenaran bersifat tunggal. Sehingga yang berbeda dianggap sebagai sesuatu yang salah. Berikut beberapa ciri gerakan radikalisme; a) mudah mengkafirkan orang lain (ideologi takfiri), b) aktivitas jihadis dengan mengatasnamakan agama padahal tidak dibenarkan oleh agama, c) menggunakan cara-cara kekerasan dalam menolak sistem yang ada, d) ingin menggantikan sistem yang ada dengan sistem yang mereka yakini, seperi Negara Islam atau khilafah.

Dalam sejarah Negara kita, juga pernah mengalami tindakan radikalisme, hal ini ditandai dengan adanya gerakan DITII. Hadirnya gerakan DITII dapat menjadi pelajaran bagi negara kita dalam mengantisipasi tindakan tersebut untuk terulang kembali. Terdapat beberapa faktor yang menyebabkan hadirnya pemahaman radikalisme: Faktor pemikiran, Faktor ekonomi (kemiskinan), Faktor politik (hubungan Internasional), Faktor sosial (fanatik), dan Faktor pendidikan (kurang inklusif). Implikasi dari meningkatnya pemahaman radikalisme dapat menyebabkan menguatnya ajaran intoleran, kelompok intoleran semakin mendominasi, dan tumbuhnya jiwa saling klaim kebenaran.

Langkah pencegahan pemahaman radikalisme dapat dilakukan dengan dua hal:

\section{Preventif}

- Meningkatkan jiwa nasionalisme kebangsaan

- Meningkatkan pemikiran yang terbuka dan toleran

- Waspada dengan provokasi dan hasutan kebencian

- Bergabung dengan kelompok atau jaringan yang positif

- Menjalankan aktifitas agama dengan toleran, tasamuh dan moderat

\section{Kuratif}

- Meberikan pemahaman terkait bahaya radikalisme

- Memberikan pemahaman agama yang baik

- Meningkatkan nilai-nilai nasionalisme

Penanya: Irvan Nofrandi

\section{Tanya Jawab}

Pertanyaan: -bukankah pengertian radikal menurut KBBI berkonotasi positif?

-kenapa ustad kerap dituding radikal?

Penanya: Wilda

Pertanyaan: -bagaimana menyikapi agama dalam politik?

-bagaimana cara melakukan revolusi mental terhadap pemahaman radikalisme?

Penanya: Hamzah

Pertanyaan: -bagaimana upaya pencegahan radikalisme dalam dunia pendidikan?

Penanya: Fajri

Pertanyaan: -apakah tindakan Islam nusantara ada hubungan dengan paham radikalisme -bagaimana cara mencegah orang yang mengatakan nasionalis tapi sebenarnya sebaliknya?

Penanya: Abdul

Pertanyaan: -apa yang harus dilakukan oleh pemerintah dalam mencegah paham radikalisme? 


\section{Jawaban}

1. Upaya menangkal radikalisme oleh pemerintah (penciptakan aturan), (membentuk instansi khusus).

2. Radikalisme dan Islam Nusantara (sebagai upaya jalan tengah yang diciptakan oleh NU dengan berlandaskan budaya).

3. Mencegah radikalisme dalam pendidikan (pemahaman tenaga pendidik, kurikulum pendidikan).

4. Agama dan politik (Indonesia adalah negara demokrasi agama yang dalam demokrasinya tersisip nilai-nilai agama).

5. Defenisi radikalisme (memang banyaknya definisi radikalisme ini menyebabkan sampai batas mana kita menyematkan arti dari kata itu sendiri).

Pemateri 2: Sadri, SIP.M.Soc.sc

\section{Pokok Pembahasan}

Dalam realitas kemasyarakatan terdapat stigma yang buruk terhadap Muhammadiyah, dimana dianggap sekuler yang memisahkan agama dan politik. Kemudian Muhammadiyah juga dianggap sebagai organisasi yang hanya ingin menikmati hasil perjuangan keislaman yang bertujuan untuk kemashlahatan bangsa. Dalam rangka menjaga masa depan Muhammadyah maka tidak diharamkan anggota Muhammdiyah untuk terlibat dengan aktifitas politik praktis. Maka seluruh angkatan muda Muhammadiyah harus mampu bermain di ranah intelektual. Akan tetapi jangan ketika bermain dengan aktifitas politik praktis maka jangan sekali-kali menjual organisasi Muhammadiyah.

\section{Langkah strategis untuk menjaga khittah Muhammadyah}

1. Menjalin komunikasi dengan seluruh elemen yang ada dalam organisasi Muhammadiyah.

2. Tingkatkan potensi dan tempatkan pada wadah yang sesuai dengan kemampuan atau skill.

3. Siapkan kader yang professional.

4. Terus mendorong terciptanya good godvernance.

\section{KESIMPULAN}

Menguatnya pemahaman radikalisme agama seiring dengan derasnya laju kemajuan teknologi dan informasi seperti media sosial. Kaum muda termasuk kelompok yang rentan dan potensial terpapar paham radikalisme agama, jika tidak memiliki pemahaman moderatisme agama yang baik. Di sisi lain, kaum muda mempunyai peran yang stretegis dalam menangkal pemahaman radikalisme. Salah satu cara dalam meningkatkan pemahaman moderatisme beragama adalah dengan melakukan pendidikan politik dalam menangkal pemahaman radikalisme terhadap kaum muda Muhammadiyah di Kota Pariaman. Pelatihan pendidikan politik deradikalisasi dalam menangkal pemahaman radikalisme dapat membangun (trust), jaringan kerja (networking) dan kerjasama (cooperation) sebagai antara Jurusan Ilmu Politik Universitas Andalas dengan Ormas Muhammadiyah.

\section{DAFTAR PUSTAKA}

Abubakar, I., Nabil, M., Wahid, A., Akhmar, A. M., Latief, H., Hemay, I., Simun, J. (n.d.). Kaum Muda Muslim Milenial Hibridasi kultural, Konersevatisme dan Tantangan Radikalisme. Jakarta.

Ahnaf, M. I. (1970). 'Struktur politik dan deradikalisasi pendidikan agama bagi anak muda di Indonesia', Jurnal Pendidikan Islam, 2(1), hal.153-171.

https://doi.org/10.14421/jpi.2013.21.153-171 
Azca, M. N. (2013). 'Yang Muda, Yang Radikal: Refleksi sosiologis terhadap fenomena radikalisme kaum muda Muslim di Indonesia pasca Orde Baru', Maarif, 8(1), hal.14-44.

Hasan, N. (2012). Islam Politik di Dunia Kontemporer, Konsep, Genealogi dan Teori. Yogyakarta: UIN Suka Press.

Hooker, G. F. and V. (2006). Voices of Islam in Southeast Asia: A Contemporary Sourcebook (Greg Fealy and Virginia Hooker, Ed.). Singapore: ISEAS.

Karwadi, K. (2014). 'Deradikalisasi pemahaman ajaran Islam', Al-Tahrir: Jurnal Pemikiran Islam, 14(1), hal.139. https://doi.org/10.21154/al-tahrir.v14i1.71

Nadirsyah Hosen. (2019). Siapa Kelompok Radikal Islam Itu? [Catatan Untuk Menteri Agama Yang Baru]. Retrieved from https://geotimes.co.id/ website:

https://geotimes.co.id/kolom/siapa-kelompok-radikal-islam-itu-catatan-untuk-menteriagama-yang-baru/

Qodir, B. S. dan Z. (2015). Gerakan Islam Non Mainstream dan Kebangkitan Islam Politik di Indonesia. Yogyakarta: Pustaka Pelajar.

Qodir, Z. (2013). 'Deradikalisasi Islam dalam perspektif pendidikan agama', Jurnal Pendidikan Islam, 2(1), hal.85-107. https://doi.org/10.14421/jpi.2013.21.85-107

Sosial, P. S. B. dan P. (2017). Executive Summary Hasil Penelitian "Radikalisme di Website and Media Sosial. Surakarta.

Sumatra Barat Jadi Sasaran Teroris? (2018). Retrieved from Republika.co.id website: https://www.republika.co.id/berita/nasional/daerah/18/08/15/pdi7mp382-sumatrabarat-jadi-sasaran-teroris

Suseno, F. M. (2014). Realisme Demokrasi Indonesia Pasca-Reformasi Demokrasi Indonesia dalam Bahaya. In A. P. dan U. Hamid (Ed.), Merancang Arah Baru Demokrasi Indonesia Pasca Reformasi (p. 263). Jakarta: Gramedia.

Zulfadli. (2017). 'Radikalisme Islam dan Motif Terorisme', AADEMIKA, 22(1), hal.194.

Zulfadli. (2018). 'Orientasi politik aktivis Eks Hizbut Tahrir Indonesia pasca dibubarkan', Kontekstualita Jurnal Penelitian Sosial Keagamaan, 35(2), hal.169-189. https://doi.org/10.30631/kontekstualita.v35i02.133 